\title{
Rock Art of the Khufu Region, Egyptian Western Desert: The Female Anthropomorphic Representations
}

\section{Rock Art of the Khufu Region, Egyptian Western Desert: The Female Anthropomorphic Representations}

\author{
Nourhan Moustafa* and Mostafa Atallah ${ }^{1}$ \\ nourhan.moustafa@pg.cu.edu.eg \& nourhan.moustafa994@gmail.com
}

\begin{abstract}
The final stage of the Holocene humid period covers approximately the sixth millennium BC. This period in the Western Desert of Egypt is connected to the late Bashandi A cultural unit (around ca. 6420 to 5700 BC) or the beginning of Bashandi B cultural unit (around 5400 or 5650 to 3950 BC) in Dakhla oasis, when the desert dwellers were hunter-gatherers. Followed by the Middle Holocene regionalization phase, which is linked to the late Bashandi B cultural unit or the early Sheikh Muftah cultural unit (approximately 3800-2900 BC) in Dakhla Oasis. Due to a fundamental climatic change in the Sahara during this phase, the Western Desert of Egypt was depopulated except for some sites with favorable conditions for living like the oases which offered water supplies. (McDonald, 2001; 2002; Riemer \& Kindermann, 2008). Fortunately, the Western Desert of Egypt conserves numerous amounts of archaeological remains of the ancient dwellers. As not all of them were buried by dunes and rock art is one of them. Thus, there are countless sandstone hills covered with engraved, pecked, and incised petroglyphs that were executed in the soft rocks (Polkowski, et al., 2013). In terms of style and elaboration, the most outstanding type of prehistoric rock art recorded in the Western Desert of Egypt is the female anthropomorphic figures. The distribution of these engravings was widely extended to be found in the Khufu region, southwest of Dakhla Oasis. Therefore, the focus of this paper's research is on studying and interpreting this striking type of figure in the Khufu region. Trying to get the best outcomes, spatial distribution, statistical, and stylistic or typological analyses have been performed over the corpus data of the female figures in the Khufu region.
\end{abstract}

Keywords: The Egyptian Western Desert, Khufu region, Middle Holocene, Rock art, Female Anthropomorphic Figures.

\section{Introduction.}

The main site Khufu 01/01 is situated about $60 \mathrm{~km}$ southwest of Dakhla Oasis. It is marked by a small, flat-topped light brown sandstone hill of about $20 \mathrm{~m} \mathrm{high}$

\footnotetext{
* Corresponding author. E-mail: nourhan.moustafa@pg.cu.edu.eg \& nourhan.moustafa994@gmail.com

${ }^{1}$ Professor of Prehistory, Egyptology Department, Faculty of Archaeology, Cairo University.
} 
(Fig. 1). The landscape of the region is hilly with countless sandstone inselbergs ranging from small single rocks to large hills up to 50 meters high (Riemer, 2006; Wagner \& Heller, 2012).

In December 2000, Carlo Bergmann was the first to spot Khufu 01/01 hill and named it "Radjedef's water mountain" following Kuhlmann (2002). This sandstone hill derives its importance mainly from the hieroglyphic inscriptions which depicted on its rock face and bear witness of a repeated presence of Egyptian expeditions during the reign of pharaoh Cheops (Khufu) and his son Djedefre in the remote Western Desert, that is why this area was named as "Khufu region", Besides, numerous depictions of prehistoric savanna fauna show that the site was already used in earlier times (Bergmann, 2001; Kuper \& Förster, 2003).

Due to the significance of the site an independent project ${ }^{2}$ has been launched within the course of the ACACIA project (Arid Climate, Adaptation and Cultural Innovation in Africa) under the name "Chufu 01/01-eine pharaonische Wüstenstation und ihr landschaftsarchäologischer Kontext" by Rudolph Kuper, as a corporate project between the German archaeological institute and the University of Cologne. This project aimed to excavate and document the main site Khufu 01/01, and to systematically survey the region. Therefore, a total of 158 archaeological sites were discovered and investigated, including a number of 112 rock art sites.

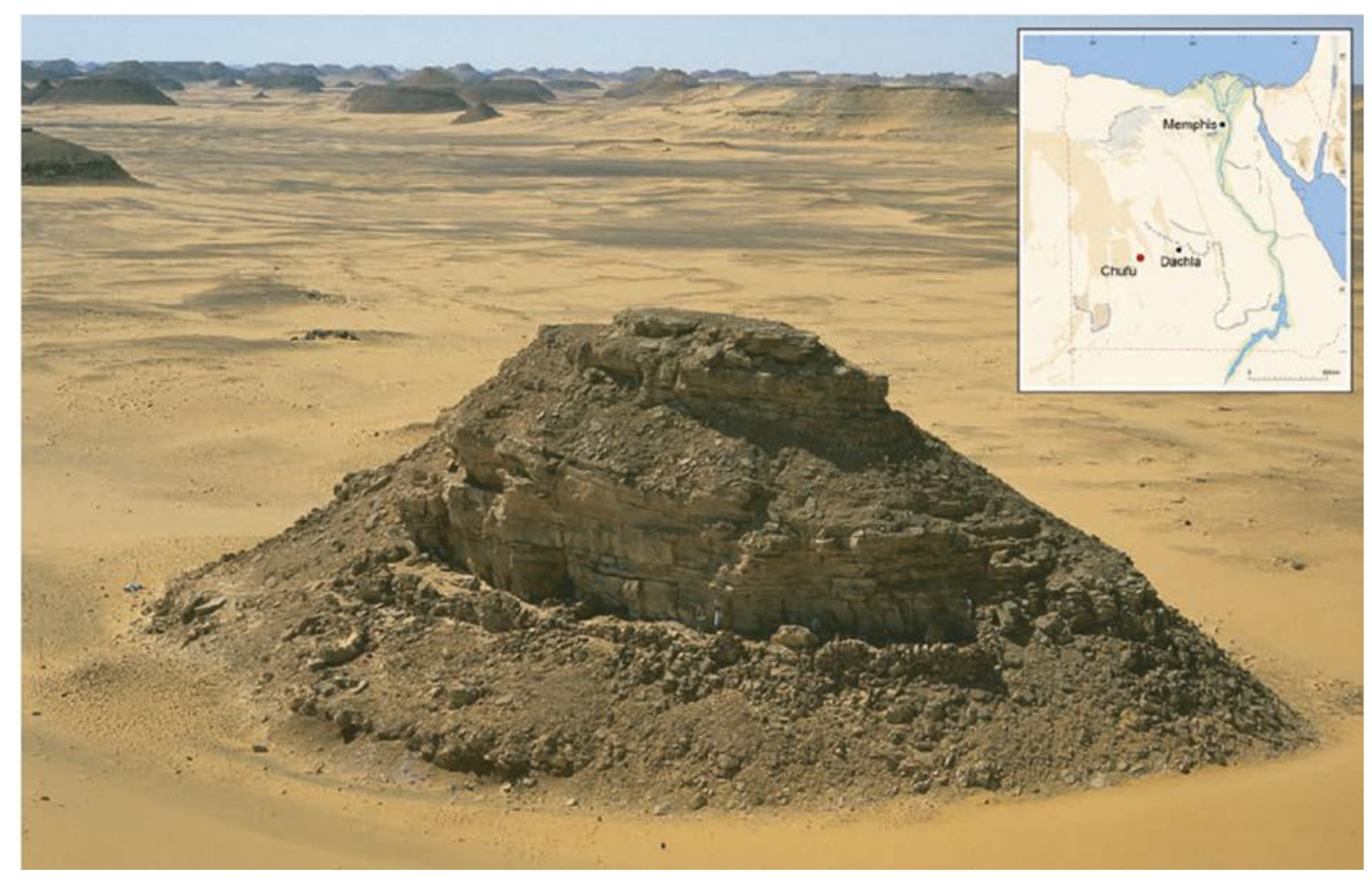

Fig.1. View of the eastern side of the main hill Khufu 01/01. (Kuper, 2016)

The researcher had not participated in the work of this excavation project. ${ }^{2}$ 


\section{Rock Art of the Khufu Region, Egyptian Western Desert: The Female Anthropomorphic Representations}

Among hundreds of petroglyphs depicted there, the female anthropomorphic figures were found, as Hans Winkler (1939) was the first to find, describe, and interpret this type of presumed woman in the eastern part of the Dakhla oasis. Recently, the spatial distribution of this striking type expanded widely to include the so-called "ladies hill" (listed as site Meri 99/36) (Riemer, 2006; 2009), and in the environs of Kharga oasis (Ikram, 2009; 2018).

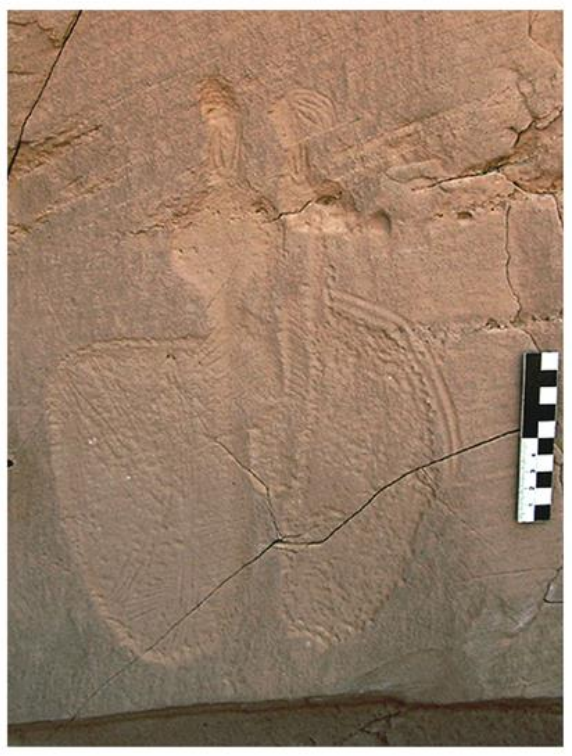

Khufu 01/08

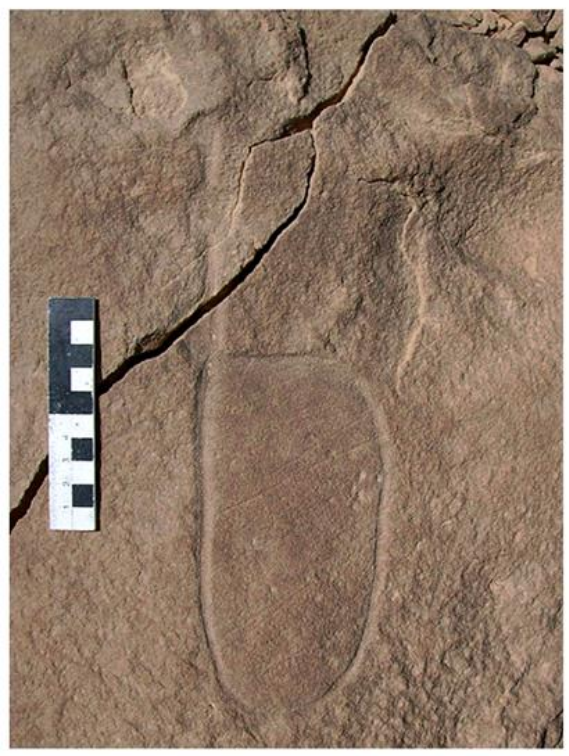

Khufu $07 / 59$

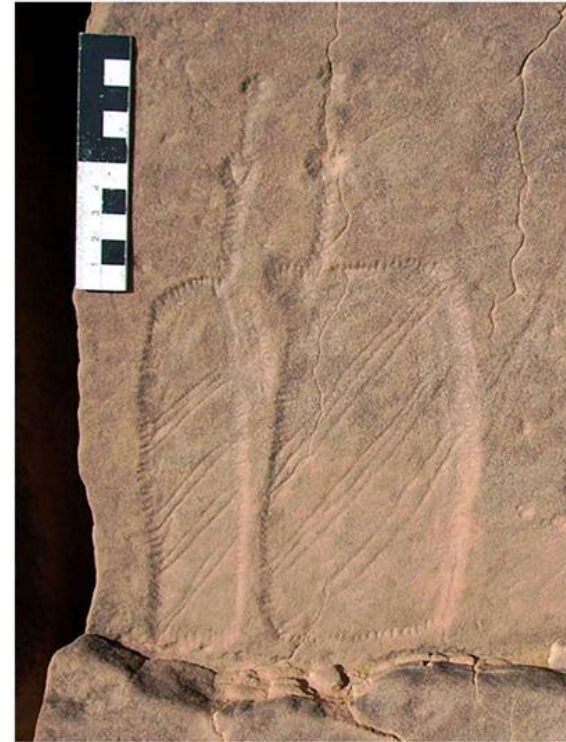

Khufu 07/56

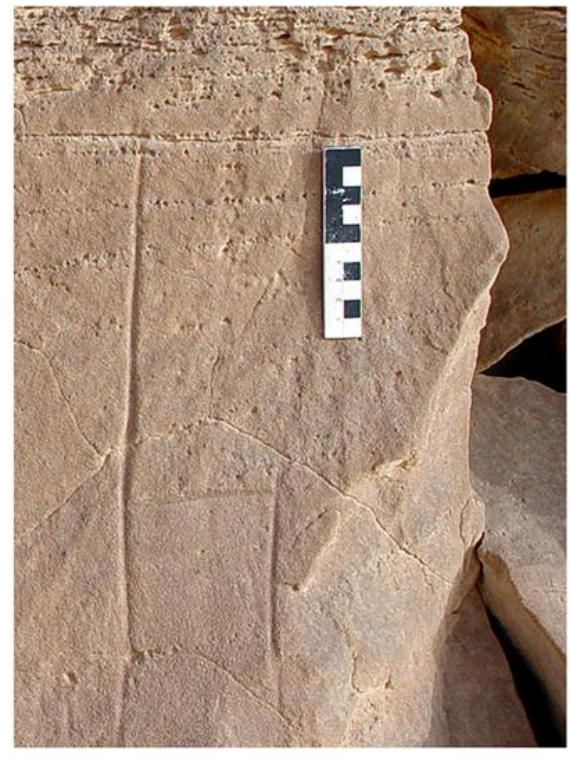

Khufu 06/31

Fig.2. Examples of the female anthropomorphic figures in the Khufu region. (Photos: J. Hempel) 
The female figures in the Khufu region are mostly depicted in profile view with just a few shown in frontal view. They are usually characterized by a schematic upper body composed of a simple head, stick-like trunk, truncated arms, and exaggerated lower body anatomies. The representations fluctuate from being very schematized forms to more elaborated examples (Fig. 2). Thus, the focus of this paper is to examine the spatial distribution of these figures in the Khufu region and analyze their attributes and characteristics to reach a satisfactory interpretation for these female figures.

\section{Materials and methods}

This study depends mainly on Wagner \& Heller (2012) who have reported on the archaeological material found in the main site Khufu 01/01, and the excavation reports, documentations, and photographs of the rest of the sites discovered within the field survey that was conducted in the region by P. Schönfeld and his colleagues, as a part of Khufu 01/01 project, provided by courtesy of R. Kuper. Therefore, the methodology in this study paper depends on performing quantitative, spatial distribution, and presence or absence analyses.

\subsection{Spatial distribution analysis}

The strength of the relationship between rock art and space derives mainly from the fact that rock art is always fixed into its place, unlike other archaeological remains that can be exchanged or traded. The distribution analysis of rock art usually provides tools to reconstruct the way space was defined and used by a specific group and illustrate the social identities in the past, but it should be viewed with caution (Lenssen-Erz, 2008; Sanz, et al., 2008; Sanz \& Fiore, 2014). The spatial distribution includes a quantitative analysis to examine the quantity of the female figures in each site, and to shed light on the sites with the highest number of female figures. As a result, a total corpus of 181 female anthropomorphic figures, which were depicted in a number of 35 rock art sites within the region has been detected.

\subsection{The attributes analysis}

To improve the identification of the supposed female figures in the Khufu region, there was a necessity to systematically decompose their process of production and to study their components or features separately. Thus, the statistical analysis which was executed on the corpus data of the females includes the quantification of their attributes.

Like all the human representations, the female figures can be studied through both morphological and anatomical criteria. Therefore, objective anthropomorphic analysis has been carried out to the whole corpus of the female figures engraved in 


\section{Rock Art of the Khufu Region, Egyptian Western Desert: The Female Anthropomorphic Representations}

the Khufu region trying to get a fundamental definition for these representations. While considering the structure or the form of the female representations in the region, specific anatomical characteristics or attributes were cautiously selected to identify the anthropomorphic form. Then, the anthropomorphic analysis has been continued by assigning a presence or absence value to the attributes for each of the depicted female figures (Fuentes, 2013; Magne \& Klassen, 1991). The specific anthropomorphic attributes are:

- Head.

- Arms.

- Hands.

- Legs.

- Feet.

Additionally, since the comprehension of figures' gender can enhance the identification of their function and contexts (Hays-Gilpin, 2004), an objective sex assessment examination has been carried out to the assemblage of the female figures to define them precisely. The sexual analysis has been conducted by assigning a presence and absence value to the primary and secondary sexual characteristics for each of the depicted female figures. Thus, considering the structure of the figures, the sexual characteristics markers, which are selfexplanatory, were determined cautiously as follows ${ }^{3}$ :

- Breast. (Primary sexual characteristic)

- Penis. (Primary sexual characteristic)

- Bulged belly. (Secondary sexual characteristic)

- Exaggerated buttock. (Secondary sexual characteristic)

\section{The bulged belly problem}

Interestingly, many of the supposed female representations have been depicted with obese or bulged bellies (Fig. 3). The interpretation of this characteristic

\footnotetext{
${ }^{3}$ The sexual characteristics' classification whether primary or secondary is not strictly biological.
} 
subjects to many debates, however Winkler (1939) and Berger (2008) see that the curved line of the ladies' abdomen symbolizes pregnancy or fertility, depending on the position of the bulged belly on the body, which subsequently can be considered as an indicator of sex, James (2010) asserted that the bulged belly is an ambiguous character and cannot be assigned as a sexual attribute by itself. Aiming to explore this character more, all combinations of the bulged belly attribute with other attributes (whether anthropomorphic or sexual) were examined to test the possibility that it can be a sexual attribute and an indicator for sex.

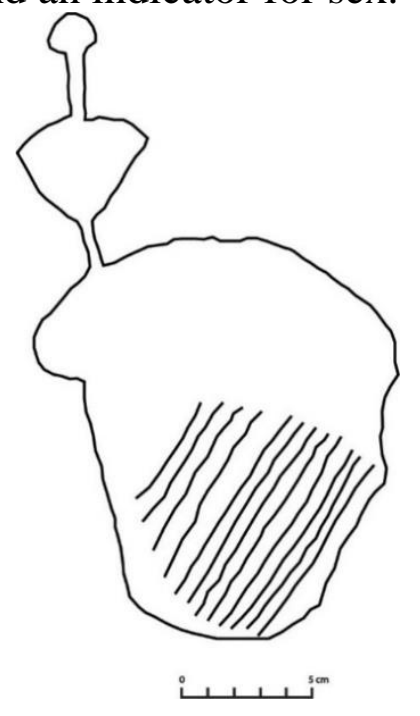

Fig. 3. Khufu 06/27. An example of the so-called pregnant lady. (Illustrated by N. Moustafa)

\section{Results and discussion.}

The distribution of the supposed female figures over the sites in the Khufu region varies significantly, Khufu 01/08 site contains 24 figures, meanwhile, each one of the sites, Khufu 02/25, 02/42, 07/28, 07/33, 07/54, 07/59, 07/69, and 08/01 contains only one figure (Fig. 4). The highest number of female figures were detected in the sites: Khufu 01/08 with 24 female figures, Khufu 06/27 with 17 figures, Khufu 01/06 with 16 figures, Khufu 01/01 with 13 figures, and Khufu 06/28 with 12 figures.

Furthermore, the result of the anthropomorphic analysis can be shown in figure 5 which illustrates the number of the individual five attributes within the female representations depicted in the region. It is obvious that the head is the most common attribute at $78.28 \%(\mathrm{n}=137)$, followed by the arms making up $6.86 \%$ $(\mathrm{n}=12)$, then the hands at $1.71 \%(\mathrm{n}=3)$, finally legs and feet have the same percentages at $1.14 \%(n=2)$. Of the corpus data $(n=175), 21.71 \%(n=38)$ do not present any of the specified anthropomorphic attributes (Fig. 6). 


\section{Rock Art of the Khufu Region, Egyptian Western Desert: The Female Anthropomorphic Representations}

Additionally, the result of the sex assessment analysis can be shown in figure 7 , which illustrates the number of the individual four characteristics within the female representations depicted in the region. Of the total corpus data $(n=175)$, The exaggerated buttock attribute is the most common sexual attribute at $93.7 \%$ $(n=164)$. Followed by the breast attribute, which makes up 59.43\% $(n=104)$, then the bulged belly characteristic at $22.85 \%(n=40)$. Finally, the penis or penis sheath attribute forms $4.57 \%(\mathrm{n}=8)$. In the light of the results, of the total corpus data, $2.29 \%(\mathrm{n}=4)$ does not display any of the sexual characteristics, $4.57 \%(\mathrm{n}=8)$ are defined as males, and $93.14 \%(\mathrm{n}=163)$ are assigned as females (Fig. 8).

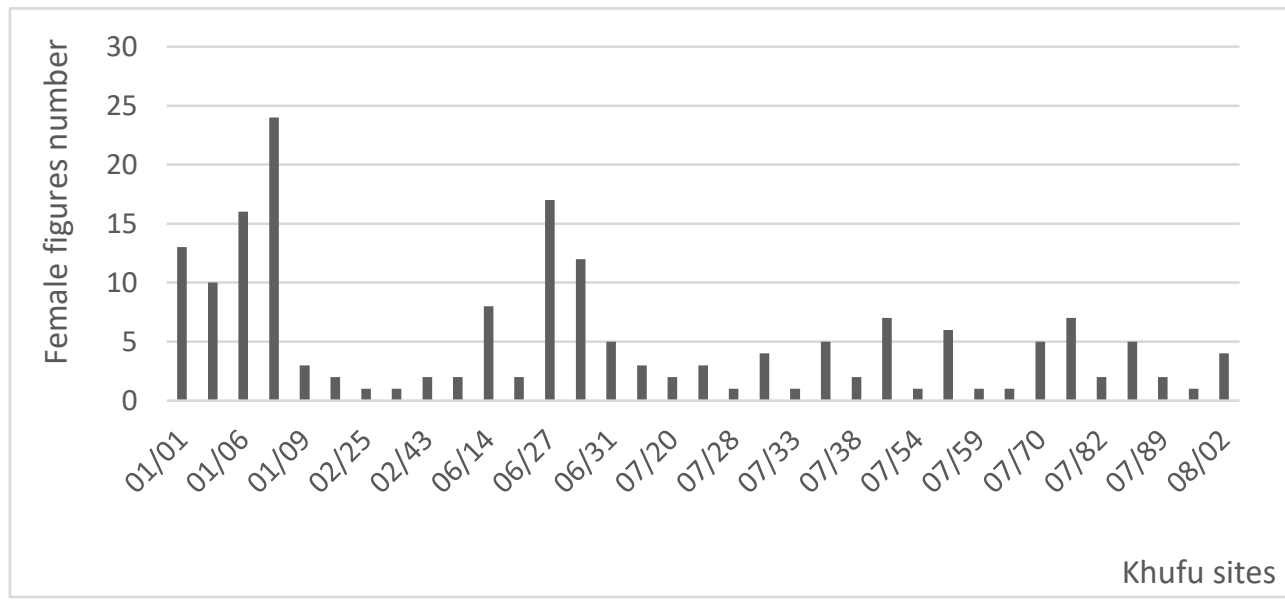

Fig. 4. The female figures' statistical distribution over Khufu region sites.

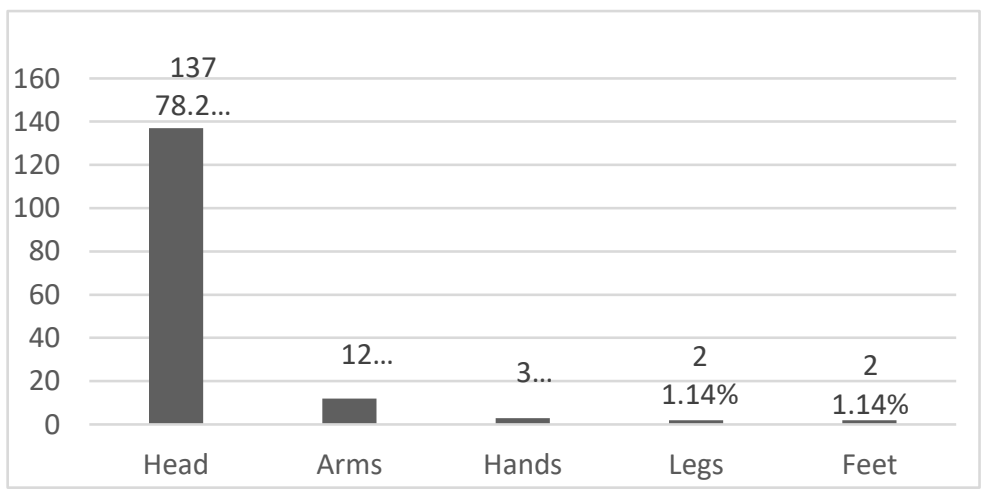

Fig. 5. The individual anthropomorphic attributes presence.

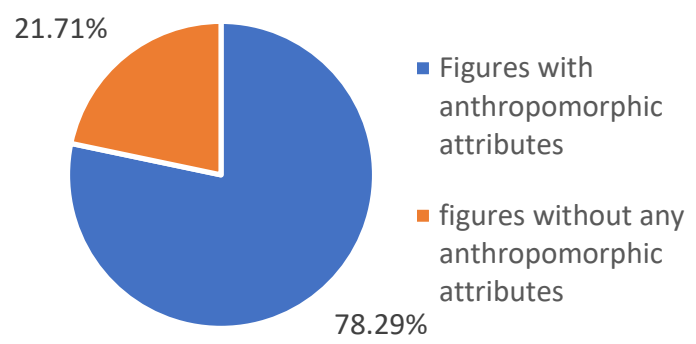


Fig. 6. The percentage of the figures that do not have any of the selected anthropomorphic attributes.

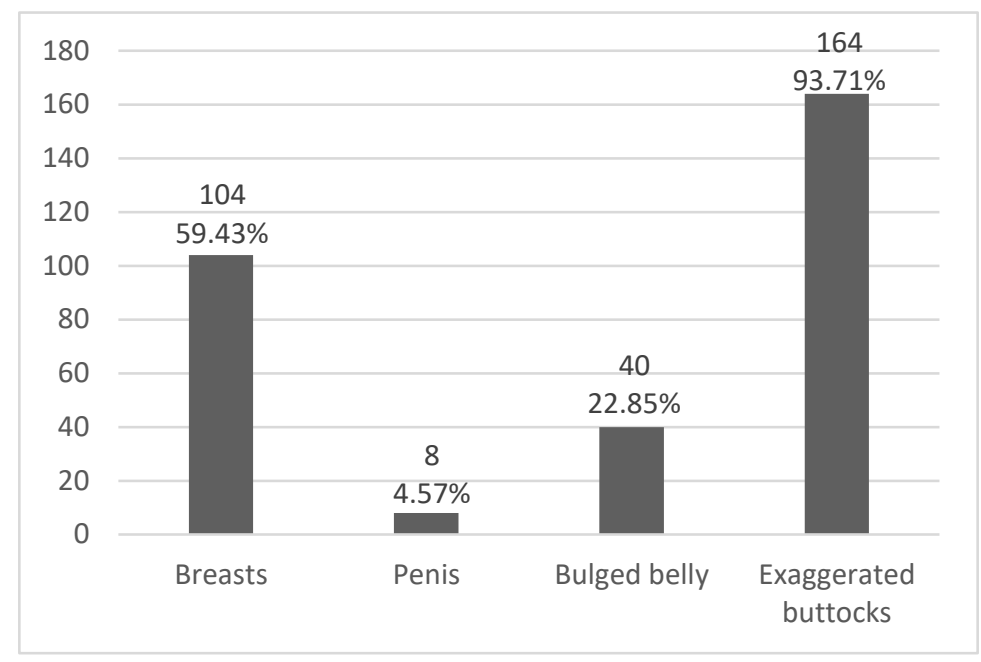

Fig. 7. The individual sexual characteristics present.

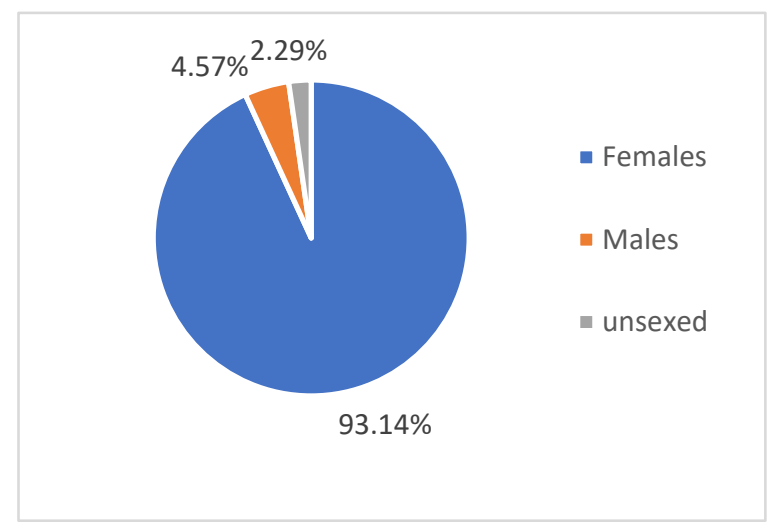

Fig. 8. The percentage of the sexed (females or males), and sexless figures that do not have any sexual characteristics.

Concerning the bulged belly, from the results of the analysis (Fig.9), all the so-called pregnant ladies have been depicted with heads implying that all of them are anthropomorphic figures. 95\% $(n=38)$ of the corpus data combine head, exaggerated buttock or dress, and bulged belly attributes, and $87.5 \% \quad(n=35)$ gathered head, breast, exaggerated buttock or dress, and bulged belly attributes. Therefore, the frequent appearance of the bulged belly characteristic combined with both the breast and the exaggerated buttock attributes indicates that the bulged belly attribute can be a minor sexual attribute. Regarding the interpretation of the bulged belly attribute, it is problematic to assert that if it symbolizes pregnancy or fertility, but depending on the results mentioned above, it can at least be considered as a sexual identification marker. 


\section{Rock Art of the Khufu Region, Egyptian Western Desert: The Female Anthropomorphic Representations}

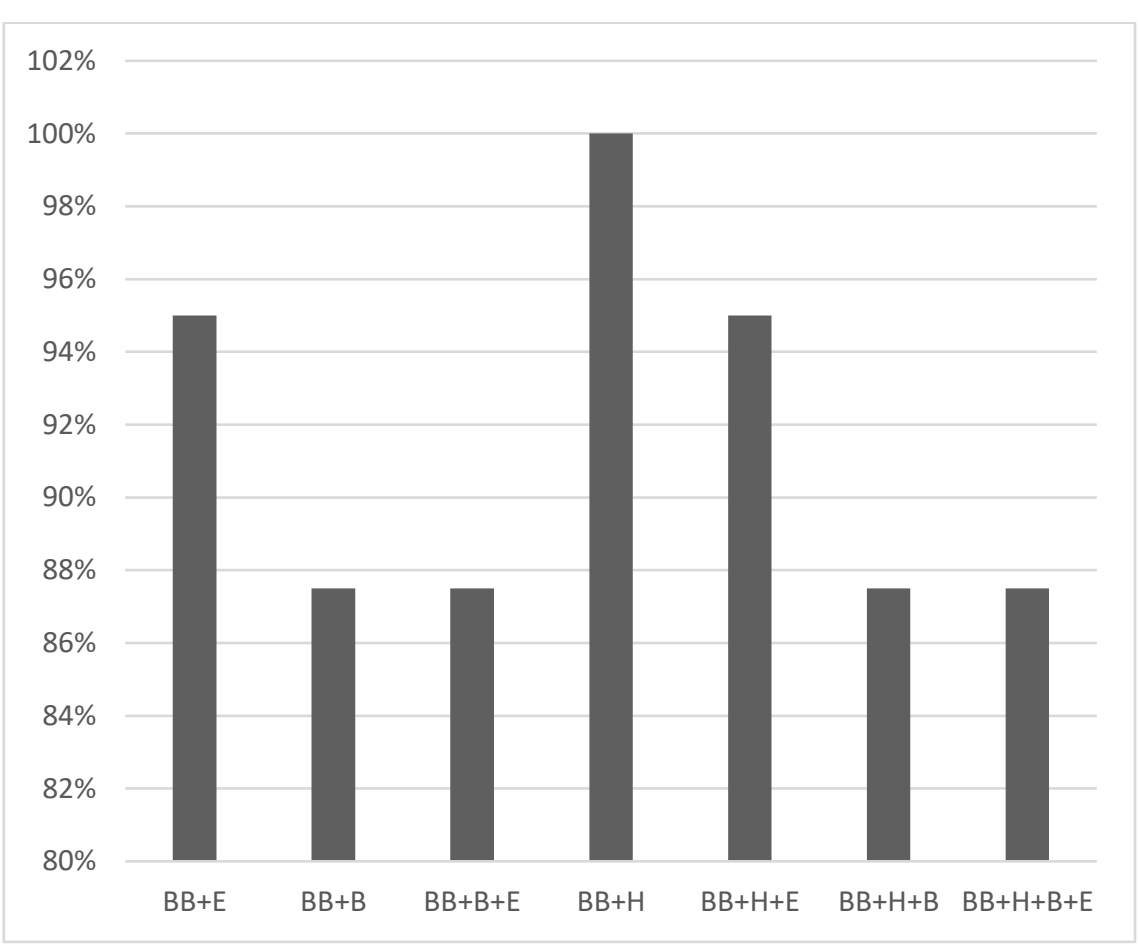

Fig. 9. All combinations of the bulged belly (BB) characteristic with other attributes; (E) exaggerated buttock, (B) breast, and $(\mathrm{H})$ head (as percentages).

\section{Conclusions}

Normally, to reach a meaning of any rock art motifs, three main levels of interpretations should be considered, the first is to identify them, the second is to search where and why they have been engraved, the third is to explore their cultural significance by identifying what they meant to the artists or producers (Taçon, 1999). Winkler (1939) was the first to explain these female figures as real statues and the pregnant figures are deities, followed by Krzyzaniak \& Kroeper (1991) who used the existence of a potentially masked figure and a scene for an animal probably sacrificed to propose that they are goddesses or female sorcerers. Anyway, it can be concluded from the presence and absence analyses above that they are female anthropomorphic representations, and the diversity of their styles and types indicates that the rock art in the region was a public activity. Therefore, despite the final interpretation or the function of these images is still a matter of debate, and the divinity explanation needs more pieces of evidence to be approved, they can be considered as a fertility symbol, adopted by the ancient oasis dwellers. And concerning the dating, these images in question are prehistoric art, depicted most likely during Neolithic Bashendi B cultural unit $\left(6^{\text {th }}\right.$ and $5^{\text {th }}$ millennium BC), with a possibility of continuation in Sheikh Muftah cultural unit. 


\section{Acknowledgment}

We would like to acknowledge Dr. Rudolph Kuper at Cologne University for providing the documentation, maps, and the unpublished photographs of the work of "Chufu 01/01-eine pharaonische Wüstenstation und ihr landschaftsarchäologischer Kontext" project, as without these images and prints, the analyses and this paper would not have been possible. Many thanks also go to Dr. Tilman Lenssen-Erz at Cologne University for his perspective on rock art research, and for giving useful feedback on the analyses. Sincere thanks must also go to Peter Schönfeld for his valuable advice on the documentation system of the project. Finally, thanks to Heinrich-Barth-Institut für Archäologie und Umweltgeschichte Afrikas at Cologne University, where the analyses were carried out. 


\section{Rock Art of the Khufu Region, Egyptian Western Desert: The Female Anthropomorphic Representations}

\section{References}

Berger, F. (2008). Rock art west of Dakhla: the 'women' from Dakhla. Rock Art Research: The Journal of the Australian Rock Art Research Association (AURA), 25(2), 137-145.

Bergmann, C. (2001). Der letzte Beduine. Meine Karawane zu den Geheimnissen der Wüste. Hamburg 2001.

Fuentes, O. (2013). The depiction of the individual in prehistory: human representations in Magdalenian societies. Antiquity, 87(338), 985.

Hays-Gilpin, K. (2004). Ambiguous images: gender and rock art (Vol. 6). Rowman Altamira.

Ikram, S. (2009). Drawing the world: petroglyphs from Kharga Oasis. Archéo-Nil, 19, 6782.

Ikram, S. (2018). Fat Ladies, Thin Men, Blobby People, and Body Parts: An exploration of human representations in the rock art of the North Kharga Basin. What Ever Happened to the People, 359-70.

James, D. S. (2010). Stepping from Winkler's Shadow: An Analysis of Supposed Female Anthropomorphs in the Rock-art of the Dakhleh Oasis Region in the Egyptian Western Desert (Doctoral dissertation, Monash University).

Krzyzaniak, L., \& Kroeper, K. (1991). A Face-mask in the Prehistoric Rock Art of the Dakhleh Oasis?. Archéo-Nil, (1), 59-61.

Kuhlmann, K. P. (2002). The "Oasis Bypath" or the issue of desert trade in Pharaonic times. Tides of the Desert-Gezeiten der Wüste, Contributions to the Archaeology and Environmental History of Africa in Honour of Rudolph Kuper, 125-170.

Kuper, R. \& Förster, F. (2003). Khufu's 'Mefat'expeditions into the Libyan Desert. Egyptian Archaeology 23. p.25-28.

Kuper, R. (2016). Mefat Für Memphis: Cheops' Expeditionen in die Libysche Wüste. MDIAK 70/71. p.285-298.

Lenssen-Erz, T. (2008). Space and discourse as constituents of past identities, in I. Domingo, D. Fiore \& S.K. May (ed.) Archaeologies of art: time, place and identity: 29-50. California: Left Coast Press.

Martin P. R. Magne, \& Klassen, M. (1991). A Multivariate Study of Rock Art Anthropomorphs at Writing-on-Stone, Southern Alberta. American Antiquity, 56(3), 389418. 
McDonald, M.M.A. (2001). The Late Prehistoric radiocarbon chronology for Dakhleh Oasis within the wider environmental and cultural setting of the Egyptian Western Desert [in:] Marlow, C.A. \& Mills, A.J. (eds.), The Oasis Papers 1: The proceedings of the First Conference of the Dakhleh Oasis Project. Dakhleh Oasis Project Monograph 6. Oxford: 26-42.

McDonald, M.M.A. (2002). Dakhleh Oasis in Predynastic and Early Dynastic times: Bashendi B and the Sheikh Muftah units. Archéo-Nil 12: 109-119.

Polkowski, P. Kuciewicz, E. Jaroni, E. \& Kobusiewicz, M. (2013). Rock art research in the Dakhla Oasis, Western Desert, Egypt-Petroglyph unit. Dakhleh Oasis Project. Sahara 24. p.101-116.

Riemer, H., \& Kindermann, K. (2008). Contacts between the Oasis and the Nile: A résumé of the Abu Muhariq Plateau Survey 1995-2002. na.

Riemer, H. (2006) Out of Dakhla: Cultural diversity and mobility between the Egyptian Oases and the Great Sand Sea during the Holocene humid phase. In: K. Kroeper, M. Chlodnicki \& M. Kobusiewicz (eds.), Archaeology of Early Northeastern Africa (Poznan: Poznan Archaeological Museum) 493-526.

Riemer, H. (2009). Prehistoric rock art research in the Western Desert of Egypt. ARCHÉO-NIL. P.31-46.

Sanz, I. D., \& Fiore, D. (2014). Style: Its role in the archaeology of art. Journal of Archaeology, 1, 141-59.

Sanz, I. D., Fiore, D., \& May, S. K. (2008). Archaeologies of art: time, place, and identity in rock art, portable art, and body art. In Archaeologies of Art: Time Place, and Identity (pp. 15-28). Left Coast Press California.

Taçon, P. S. (1999). Andrée Rosenfeld and the Archaeology of Rock-Art 1. Archaeology in Oceania, 34(3), 95-102.

Wagner, G. \& Heller, K. (2012). Chufu 01/01- a pharaonic outpost in the Western Desert of Egypt. Prehistory of North-eastern Africa: New Ideas and Discoveries. Studies in African Archaeology, 11, 349-64.

Winkler, H. (1939). Rock drawings of southern Upper Egypt. II. Sir Robert Mond Desert Expedition. EES 27. London. 